\title{
ANALISIS FAKTOR YANG MEMPENGARUHI MINAT MASYARAKAT PADA PRODUK KREDIT UNION (CU) SEMARONG KECAMATAN TAYAN HILIR
}

\author{
Xaverius Very, Aminuyati, Okianna \\ Program Studi Pendidikan Ekonomi FKIP Untan Pontianak \\ Email : xaveriusverry24@gmail.com
}

\begin{abstract}
Abstrack
This study aims to determine the analysis of public interest in $C U$ Semarong products. The research method used is descriptive research in the form of qualitative research. The data sources of this study used data from interviews and observations, consisting of 5 respondents as $C U$ members and 1 respondent as administrative staff. To test the validity of the research data, triangulation of sources and theories was carried out. Based on the tests conducted, this study shows that people's interest in saving is influenced by 2 significant factors, namely location and reputation factors. Close location, good road access, has a good name so that customers feel comfortable and safe in choosing savings products at the Semarong Tayan Hilir CU and the public's interest in choosing loan products at the Semarong Tayan downstream $C U$ is influenced by 3 factors, namely Promotion, Product Knowledge, and Quality of Service. Promotions are carried out by distributing pamphlets/brochures, via the internet, and social media, spreading knowledge to the public so that it raises people's curiosity to find out more by visiting branch offices, the services they provide are also good, polite, courteous, thus attracting public interest. to borrow at CU Semarong.
\end{abstract}

\section{Keywords: Interests, Society, CU Semarong Products.}

\section{PENDAHULUAN}

\section{Latar Belakang}

Minat dapat dikatakan suatu keinginan yang timbul dari suatu perhatian seseorang terhadap barang, benda atau dapat juga dikatakan dorongan ingin melakukan sesuatu kegiatan tertentu. Menurut (Sudirman, 2003. p. 76) minat seseorang terhadap suatu objek akan lebih kelihatan apabila objek tersebut sesuai sasaran dan berkaitan dengan keinginan dan kebutuhan seseorang yang bersangkutan. kecenderungan itu ditandai dengan rasa senang atau ketertarikan pada objek tertentu disertai dengan adanya pemusatan perhatian kepada objek tersebut dan keinginan untuk terlibat dalam aktivitas objek tersebut karena dirasakan bermakana bagi dirinya dan ada harapan yang menjadi tujuannya.

Pilihan menabung dewasa ini semakin banyak, tidak hanya pada lembaga perbankan, tetapi juga dapat dilakukan di Lembaga keuangan lainnya, misalnya melalui Credit Union (CU) atau lembaga keuangan yang di dalamnya berkumpul orang yang saling percaya dan berwatak sosial, dengan tujuan untuk kesejahteraan bersama. Credit Union (CU), diambil dari bahasa Latin "credere" yang artinya percaya dan "union" atau "unus" berarti kumpulan. Sehingga "Credit Union" memiliki makna kumpulan orang yang saling percaya, dalam suatu ikatan pemersatu dan sepakat untuk menabungkan uang mereka, sehingga menciptakan modal bersama untuk dipinjamkan kepada anggota dengan tujuan produktif dan kesejahteraan. Menurut (Oeriang, 2019. p.17) credit union adalah sebuah lembaga keuangan koperasi yang dimiliki dan dikendalikan oleh anggotanya. Credit union tidak untuk profit (non for profit) dan hadir memberikan tempat yang aman, nyaman bagi anggota untuk menyimpan uang dan memperoleh pinjaman serta pelayanan lainnya dengan harga yang bersaing.

Banyak hal yang menjadi faktor minat seseorang untuk berhubungan dengan lembaga keuangan, baik sebagai kreditor 
maupun debitor. Alasan masyarakat berhubungan dengan lembaga keuangan ini antara lain: balas jasa dari modal yang disetor, keamanan, fasilitas/kemudahan, pemerolehan jasa pembiayaan, dan pertimbangan sistem perbankan yang berlaku. (Kusumo, 2019. p.1) bahwa sektor jasa merupakan sektor yang paling besar mengalami perubahan akibat dari cepatnya perubahan yang dialami oleh faktor lain, seperti perubahan teknologi yang secara langsung menaikkan iklim kompetisi didalam industri, karena itu para pengelola credit union berusaha untuk memberikan pelayanan yang terbaik kepada anggotanya demi menarik minat masyaraktat untuk mempergunakan produk-produk yang ada pada credit union baik sebagai kreditor maupun debitor. Lembaga keuangan yang akan diteliti pada penelitian ini adalah CU Semarong kantor cabang Tayan Hilir, Kabupaten Sanggau, Provinsi Kalimantan Barat.

Berdasarkan hasil pra observasi, nilai-nilai yang ada pada CU SEMARONG menerapkan prinsip-prinsip koperasi, tata kelola CU yang sehat, nilai-nilai inti, rencana suksesi dan lima pilar Credit Union. CU SEMARONG terus melakukan inovasi pada produk dan pelayanan secara profesional berbasis teknologi serta mengembangkan usaha diberbagai sektor untuk CU SEMARONG yang berkelanjutan. CU SEMARONG hadir untuk meningkatkan taraf hidup anggota dengan menyediakan produk yang menjawab kebutuhan anggota agar semakin mandiri dalam bidang keuangan dan tetap berpegang teguh pada SEMANGAT GOTONG ROYONG. Sebagai salah satu koperasi lembaga kepercayaan masyarakat harus mampu memberikan pelayanan yang berkualitas untuk memberikan kepuasan bagi anggota. Peningkatan pelayanan CU Semarong dilakukan dengan perluasan jaringan maupun dalam bentuk kerja sama dengan lembaga lain serta fasilitas contohnya pengadaan ATM, sehingga memudahkan anggota dalam bertransaksi. Memiliki sejumlah strategi pemasaran dalam meningkatkan jumlah anggota untuk masuk menabung dan meminjam. Apalagi saat sekarang ini sesuai perkembangan teknologi dan untuk mencapai tujuanya mensejahterakan anggotanya maka Credit
Union (CU) Semarong menyediakan berbagai macam produk simpanan dan pinjaman yang sesuai kebutuhan anggotanya. Karakteristik tersebut diharapkan dapat menarik minat masyarakat untuk memilih produk-produk pada CU Semarong. Produk-produk pinjaman yang ada pada CU Semarong yaitu (1) Pinjaman Kapital Murni yaitu pinjaman yang diberikan kepada anggota dan tidak boleh dibawa pulang akan tetapi dimasukkan Kembali ke simpanan anggota. (2) Pinjaman semi kapital yaitu diberikan hanya kepada anggota, Sebagian dibawa pulang, Sebagian masuk ke simpanan. Pinjaman ini contohnya dengan tujuan usaha produktif, konsumtif atau kesejahteraan. (3) PILAR (Pinjaman Lancar) yaitu pinjaman yang diberikan kepada anggota untuk mengatasi kebutuhan mendesak. (4) Pinjaman UMKM yaitu pinjaman yang diberikan kepada anggota untuk modal. Pinjaman Konsumtif yang diberikan kepada anggota untuk membeli sesuatu misalnya, perumahan, kendaraan, Pendidikan, atau untuk berobat.

Pada tahun 2020 ini Credit Union CU Semarong memiliki 3.822 anggota. Berikut jumlah anggota yang memilih produk simpanan dengan 3.822 anggota SAHAM dan SETARA SAHAM. Sedangkan untuk jumlah anggota yang juga menggunakan produk simpanan NON SAHAM terdata 1737 anggota SIBUHAR, 519 anggota SIMPEL, 6 anggota SITOUR, 17 anggota SIHARTA, dan 25 anggota SIPENDIK. Sedangkan jumlah anggota yang memilih produk pinjaman adalah 520 pinjaman kapital murni. 1230 pinjaman semi kapital, 1560 pinjaman UKM, dan 987 pinjaman konsumtif. Dari paparan data diatas, terlihat ada beberapa produk simpanan dan pinjaman yang sedikit peminatnya. produk adalah segala sesuatu yang dapat ditawarkan kemasyarakat untuk mendapatkan perhatian, dibeli, digunakan, atau dikonsumsi yang dapat memuaskan keinginan atau kebutuhan. Sedangkan produk tabungan yaitu produk yang dikeluarkan bank kepada nasabah untuk dijadikan pertimbangan dan pilihan yang dapat dimanfaatkan nasabah sesuai kebutuhan yang adanya reputasi yang baik dalam sebuah perusahaan bank akan menimbulkan kepercayaan bagi nasabahnya. Suatu kepercayaan adalah pikiran deskriptif oleh 
seorang mengenai suatu hal. Reputasi menurut Kamus Besar Bahasa Indonesia adalah nama baik. Pandangan paling dominan pada literatur menunjukkan bahwa sikap terhadap merek yaitu reputasi atau penyedia jasa lebih merupakan evaluasi keseluruhan jangka panjang dibanding elemen kepuasan.

Peneliti dalam penelitian ini akan menganalisis faktor minat masyarakat terhadap produk simpanan dan pinjaman Credit Union (CU) Semarong tayan hilir. Rendahnya minat masyarakat terhadap beberapa produk Credit Union (CU) Semarong, dan persaingan antar sesama lembaga keuangan menjadialasan dilakukan penelitian ini. Peneliti tertarik untuk mengetahui faktor apa saja yang mempengaruhi minat masyarakat dengan ditinjau dari Faktor Instrinsiknya yaitu pengetahuan, reputasi dan kualitas pelayanan. Serta faktor Ekstrinsik yaitu lokasi dan promosi dalam pengambilan keputusan untuk memilih produk simpanan dan pinjaman. Atas dasar inilah penulis mengambil judul skripsi "Analisis Minat Masyarakat Pada Produk Credit Union (CU) Semarong Di Kecamatan Tayan Hilir”. Hasil penelitian diharapkan dapat membantu perusahaan mensosialisasikan serta mempromosikan ke masyarakat luas untuk menggunakan produk di CU Semarong Tayan hilir.

\section{METODE PENELITIAN}

Jenis penelitian ini adalah penelitian kualitatif deskriptif, penelitian ini mempelajari masalah-masalah dalam masyarakat, serta tata cara yang berlaku dalam masyarakat serta situasi-situasi tertentu, termasuk tentang hubungan, kegiatankegiatan, sikap-sikap, pandangan- pandangan serta proses-proses yang sedang berlangsung dan pengaruh-pengaruh dari suatu fenomena. Metode penelitian ini digunakan peneliti untuk memperoleh data berupa kata-kata yang dipaparkan dan penjelasan yang objektif khususnya mengenai pemahaman masyarakat terhadap CU Semarong serta faktor-faktor yang mempengaruhi minat masyarakat Tayan Hilir dalam memutuskan memilih produkproduk yang ditawarkan pada CU Semarong

Sumber atau data yang peneliti peroleh langsung dari lapangan tanpa melalui perantara, yang didapat dari individu atau perorangan. Metode yang digunakan dalam penelitian ini adalah metode wawancara yang didapat dengan wawancara secara langsung dengan nasabah dan staf CU Semarong Tayan Hilir yang peneliti jadikan sebagai informan. Data yang didapat dari literatur yang tersedia dan berhubungan dengan permasalahan yang diteliti. Dalam hal ini data yang dicari dan temukan dari bacaan-bacaan seperti jurnal, skripsi terdahulu, buku, dokumen-dokumen, internet, dan sumber yang tertulis lainnya.

Teknik pengumpulan data dalam penelitian ini terdiri dari tiga tahap sebagai berikut:

\section{a) Observasi}

Berupa pengamatan dan penelitian yang dilakukan secara langsung dengan dengan nasabah CU Semarong Tayan Hilir, berupa catatan data- data secara keseluruhan dengan tanya jawab kepada dengan nasabah CU Semarong Tayan Hilir yang berhubungan dengan pengetahuan masyarakat tentang CU Semarong Tayan Hilir, dengan alat bantu video serta poto dokumentasi. Hasil pengamatan digunakan peneliti sebagai informasi tambahan dalam penelitian.

\section{b) Wawancara}

Metode ini digunakan untuk mencari data langsung dari informan untuk mendapatkan data yang sesuai dengan tujuan penelitian. Adapun pihak yang diwawancarai adalah dengan nasabah $\mathrm{Cu}$ Semarong Tayan Hilir. Semua itu dilakukan untuk mengetahui seberapa jauh pengetahuan dan minat masyarakat terhadap produk simpanan dan pinjaman yang ada di CU Semarong Tayan Hilir.

\section{c) Kepustakaan}

Data ini berupa data-data tertulis yang mengandung keterangan dan penjelasan serta pemikiran tentang fenomena yang masih aktual dan sesuai dengan masalah penelitian. Penulis menghimpun dokumen, seperti arsip atau data yang berhubungan dengan lokasi atau objek penelitian yang salah satunya peneliti dapat data tentang sejarah berdirinya CU Semarong Tayan Hilir, pertumbuhan dan perkembangannya, letak geografis, serta kegiatan-kegiatan yang pernah dilakukan untuk menarik minat masyarakat menabung atau meminjam di $\mathrm{Cu}$ Semarong TayanHilir.

\section{d) Instrumen Pengumpulan data}

Instrumen penelitian ialah alat bantu 
yang dipilih dan digunakan oleh peneliti selama melakukan penelitian dan pengambilan data, antara lain:

1) Camera, ialah instrumen atau alat bantu yang peneliti gunakan dalam melakukan observasi dan dalam mengambil data tertulis, dalam bentuk poto serta rekaman.

2) Pedoman wawancara, ialah instrumen yang peneliti gunakan dalam melakukan wawancara kepada informan.

3) Dokumentasi ialah instrumen untuk kepustakaan berupa arsip-arsip atau data tentang masyarakat dan wilayah dari komplek perumahan perumdam itu sendiri, untuk mengetahui karakteristik atau gambaran dariobjek penelitian.

Penelitian kualitatif harus mengungkap kebenaran yang objektif. Karena itu keabsahan data dalam sebuah penelitian kualitatif sangat penting. Melalui keabsahan data kredibilitas (kepercayaan) penelitian kualitatif dapat tercapai. Dalam penelitian ini untuk mendapatkan keabsahan data dilakukan dengan triangulasi. Adapun triangulasi adalah teknik pemeriksaan keabsahan data yang memanfaatkan sesuatu yang lain di luar data itu untuk keperluan pengecekan atau sebagai pembanding terhadap data triangulasi dengan sumber berarti membandingkan dan mengecek balik derajat kepercayaan suatu informasi yang diperoleh melalui waktu dan alat yang berbeda triangulasi dengan sumber yang dilaksanakan pada penelitian ini yaitu membandingkan hasil wawancara dengan isi dokumen yang berkaitan. peneliti memfokuskan faktor-faktor yang dapat memepengaruhi minat masyarakat terhadap produk CU Semarong yaitu Faktor Instrinsiknya yaitu pengetahuan pribadi masyarakat terhadap produk yang dapat memenuhi kebutuhannya, reputasi perusahaan yang mendorong rasa percaya masyarakat memilih produk dan kualitas pelayanan yang nyaman CU Semarong. Serta faktor Ekstrinsik yaitu lokasi yang dilihat dari letak geografisnya dan promosi yang dilakukan CU Semarong dalam pengambilan keputusan untuk memilih produk simpanan dan pinjaman.

Data wawancara dalam penelitian adalah sumber data utama yang menjadi bahan analisis data untuk menjawab masalah penelitian. Analisis data dimulai dengan melakukan wawancara mendalam dengan informan. Setelah melakukan wawancara, peneliti membuat transkip hasil wawancara dengan cara memutar kembali rekaman wawancara kemudian menuliskan kata-kata yang sesuai dengan apa yang ada direkaman tersebut. Setelah peneliti menulis hasil wawancara ke dalam transkip, selanjutnya peneliti membuat reduksi data dengan cara abstraksi, yaitu mengambil data yang sesuai

dengan konteks penelitian dan mengabaikan data yang tidak diperlukan.

\section{HASIL PENELITIAN DAN PEMBAHASAN}

CU Semarong berdidri di Sosok, pada tanggal 7 Maret 1993 yang diprakarsai oleh Pastor Drs. Antonius Kalvin, bersama tokoh masyarakat umat katolik paroki Kristus Raja Sosok. Pada saat ini jumlah anggota pada awalnya 20 orang dan jumlah aset saat itu $\mathrm{Rp}$ 229.600,00. Pada tanggal 25 s/d 27 Febuari 1993, diadakan pelatihan dasar perdana dengan peserta 20 orang. Setelah pelatihan dasar yang diadakan pembahasan nama $\mathrm{CU}$ yang akan dibentuk. Dari berbagai usulan disepakatilah Filosopi "SEMANGAT GOTONG ROYONG" yang disingkat dengan nama SEMARONG. Dengan dibentuknya kepengurusan pertama yang dikukuhkan oleh Pastor Drs. Antonius Kalvin Pr pada tanggal 27 Febuari 1993. CU SEMARONG mendapat pengakuan legalitas dari departemen koperasi pengusaha kecil dan menengah pada tahun 1999 dengan nomor: 060/BH/X.2 tgl 25 oktober 1999. Memperhatikan wilayah pelayanan CU Semarong tidak hanya diwilayah kabupaten Sanggau maka tanggal

22 September 2011 melakukan perubahan badan hukum tingkat provinsi dengan nomor 060.a/BH/PAD/X tanggl 22 September 2011. Surat ijin usaha simpan pinjamn nomor 503/06/IUSP/DPMPTSPC/IX/2017 tanggal 28 September 2017. CU Semarong berubah menjadi koperasi simpan pinjam (KSP) SEMARONG.

Peneliti melakukan observasi di CU Semarong Tayan Hilir pada tanggal 2 Agustus 2021, wawancara dengan 5 orang anggota CU Semarong pada tanggal 3 Agustus 2021 dan 4 Agustus 2021. Berikut hasil analisis data berdasarkan hasil observasi, wawancara, dan 
kepustakaan:

\section{1) Hasil Observasi}

Observasi dilaksanakan pada tanggal 2

Agustus 2021, dengan mengumpulkan data berupa pengamatan secara langsung

mengenai lokasi, pengetahuan dan produk, reputasi, kualitas pelayanan dan promosi di CU Semarong Tayan Hilir berada pada jalan hujan emas kecamatan tayan hilir kabupaten

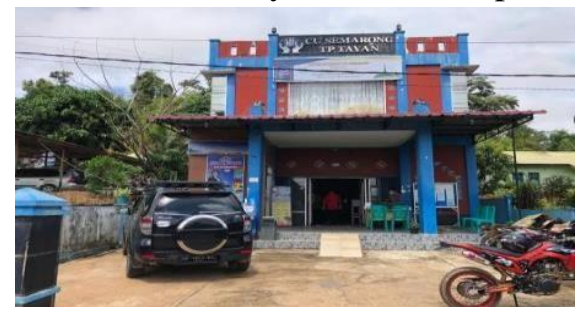

Gambar 1.Kantor CU Semarong Tayan Hilir

\section{2) Faktor Pengetahuan dan Produk}

Pengambilan keputusan nasabah untuk menggunakan suatu produk atau jasa selalu diawali dengan adanya informasi yang didapat mengenai barang atau jasa tersebut meliputi tentang informasi produk yang ada pada CU semarong, konsep dan mekanisme CU semarong, dan akad-akad yang digunakan

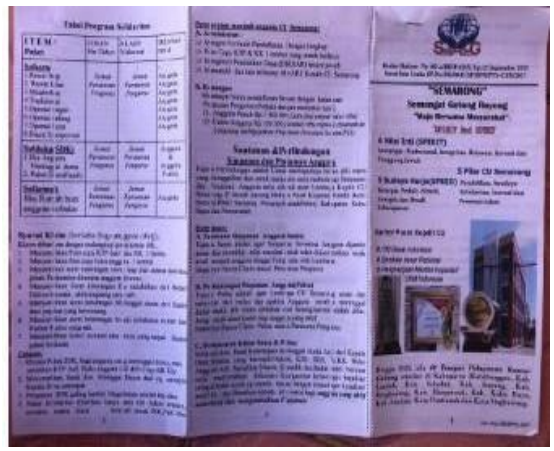

sanggau, berdasarkan hasil observasi lokasi ini cukup strategis karena aksesnya mudah dijangkau, jalan menuju lokasi juga baik, ramai dilalui masyarakat dan dekat dengan beberapa tempat usaha, lokasi parkir yang cukup memadai. Berikut letak lokasi CU Semarong Tayan Hilir:

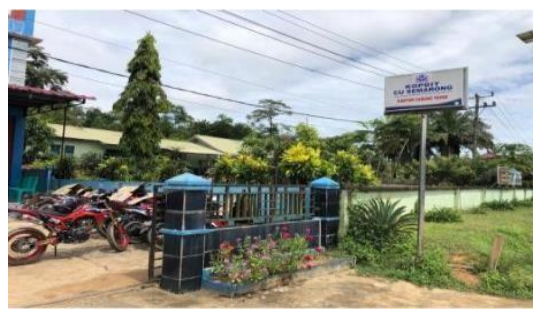

Gambar 2. Plang nama CU Semarong

dalam CU semarong. Informasi tersebut disampaikan CU Semarong dengan menyajikan secara lengkap informasi produk pada brosur dan $\mathrm{CU}$ semarong juga menyediakan formulir pendaftaran. Berikut disajikan gambar brosur dan formulir pendaftaranmya:

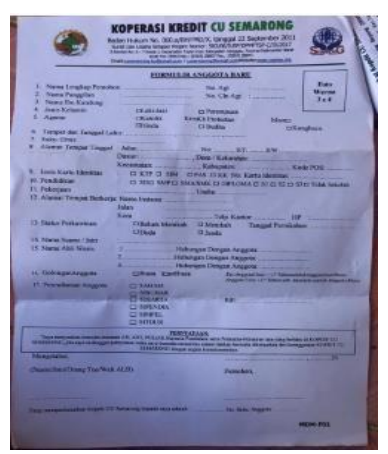

Gambar 2. Browser CU Semarong dan formulir

(Simpanan Tanah dan Perumahan) dan SIKENDA (Simpanan Kendaraan).Adapun produk-produk simpanan yang ditawarkan lembaga ini meliputi meliputi PINJAMAN UMUM, adalah pinjaman yang diberikan kepada anggota untuk kebutuhan konsumtif, produktif, kesejahteraan, berobat, pendidikan, setara saham dan kapitalisasi, PINJAMAN MITRA Pinjaman yang diberikan kepada nasabah baik yang sudah menjadi anggota Lembaga maupun yang belum menjadi
anggota,PITARUM (Pinjaman tabungan perumahan),PIKENDA(Pinjamankendaraan). Mekanisme peminjaman tentunya harus berstatus sebagai anggota dan tentunya melakukan proses suatu permohonan kredit, penyidikan dan analisis, keputusan persetujuan atau penolakan permohonan, pencairan kredit, administrasi, pengawasan dan pembinaan serta perluasan kredit. Syarat untuk menjadi anggota mengisi formulir, foto copy KTP \& KK, mengikuti DIKSAR secara 
penuh, mematuhi dan taat terhadap AD/ART Kopdit CU Semarong, membayar uang pendaftaran, lebih lengkapnya bisa dilihat pada brosur.

Berdasarkan hasil wawancara mengenai pengetahuan nasabah tentang produk-produk yang ditawarkan CU Semarong Tayan Hilir, ada yang mengatakan mereka mengetahui $\mathrm{CU}$ semarong dari plang yang jelas terpasang di tepi jalan, kemudian ada teman saya juga yang sudah menjadi anggota, ada banyak keuntungan menjadi anggota CU Semarong karena ada banyak jenis pinjaman yang dapat dipilih tergantung kebutuhan serta bisa membantu ketika dalam kesulitan keuangan. Sebagian ada yang tertarik dengan produk simpanan karena bunga yang ditawarkan cukup besar dibandingkan ketika mereka menabung di bank, contohnya simpanan pendidikan karena mengingat biaya pendidikan yang semakin hari semakin mahal, jadi saya rasa perlu untuk menyisihkan sebagian daripenghasilan saya buat persiapan pendidikan anak nya dimasa depan. Dimana lembaga penyedia jasa yang serupa misalnya jenis ansuransi dirasa mereka kurang terpercaya dan sulit untuk mengklaim. Ada juga yang memilih produk simpanan hari tua. Selain itu banyak juga yang memilih produk pinjaman pinjaman UMKM karena sebagian besar anggota disana banyak yang mempunyai Usaha Mikro kecil Menengah, sehingga mereka memerlukan modal untuk mengembangkan usahanya.

\section{3) Faktor Reputasi}

Reputasi yang baik dan terpercaya merupakan salah satu modal utama dalam bersaing suatu lembaga keuangan. Adanya reputasi yang baik dalam sebuah perusahaan akan menimbulkan kepercayaan bagi nasabahnya. Reputasi yang dimaksud dalam hal ini adalah memiliki nama baik dimata masyarakat. Salah satu strategi $\mathrm{Cu}$ semarong memperkenalkan diri dengan masyarakat yaitu ikut terlibat aktif dalam kegiatankegiatan sosial seperti donor darah dan mengadakan tornament bola volly.

Hasil wawancara mengenai reputasi $\mathrm{CU}$ Semarong Tayan Hilir, mereka tidak pernah mendengar CU semarong terkena masalah hukum, sikap karyawannya baik-baik, ramah, mereka juga senyum, mau menyapa, ketika melayani anggotanya. proses administrasinya juga cepat, ketika semua syarat semua sudah terpenuhi. CU semarong juga menjaga keamanan dan kenyamanan dalam bertransaksi. Mereka juga merespon baik ketika ada komplain, sabar dalam melayani anggotanya.

Peneliti menyimpulkan bahwa reputasi CU Semarong dimata masyarakat bernilai positif karena profesionalannya yang bergerak dalam koprasi kredit mereka selalu menjaga dengan baik hubungan dengan anggotah serta juga tegak dengan hukum, buktinya hingga saat ini CU Semorong tidak mempunyai masalah dengan hukum tentang keuangan anggota serta mempunyai reputasi yang baik di masyarakat.

\section{4) Kualitas pelayanan}

Suatu produk dapat memberikan kualitas yang berkesan ketika dapat memenuhi kebutuhan nasabah sesuai dengan apa yang diharapkannya. Kebutuhan nasabah sesuai dengan apa yang diharapkannya meliputi karyawan di CU Semarong cepat dalam melayani nasabah, Prosedur pelayanan tidak berbelit-belit, respon yang cepat dalam menangani keluhan nasabah. Dalam industri jasa, setiap orang merupakan unsur vital dalam bauran pemasaran jasa. Kebijakan pemasaran lembaga yang berkaitan dengan orang meliputi memberikan pelayanan yang baik kepada anggota CU, keramahan dalam memberikan pelayanan, teliti dalam melakukan pekerjaan, mengoptimalkan pengusaaan pekerjaan dan mengutamakan kepuasan anggota. Salah satu bentuk kebijakan pemasaran yang dilakukan adalah dengan menyediakan mesin ATM, agar nasabah merasa nyaman dan lebih gampang dalam bertransaksi.

Berdasarkan hasil wawancaranya mengenai kualitas pelayanan CU Semarong Tayan Hilir sangat mengutamakan keamanan dan kenyamananpelayanan secara optimal dari segi pelayanan kepada nasabah oleh custumer CU Semarong. Pada saat pengajuan kredit mereka menjelaskan secara detail tentang jumlah yang bisa di dapatkan dengan jangka 
waktu yang bisa dipilih, yang tentuntanya semakin lama jangka waktu yang kita pilih bunganya semakin besar. Akan tetapi dijelaskan pula apabila tertib membayar tepat waktu, maka mereka akan mendapat balas jasa pinjaman dari total bunga yang telah dibayarkan, sebaliknya apabila kita tidak tepat waktu, maka kita dikenakan denda.

Penulis menyimpulkan bahwa pelayanan CU Semarong dimata masyarakat bernilai positif, karena terlihat dari cara mereka menghargai dan melayani nasasbah dengan baik. CU Semarong selalu berusaha mewujudkan pelayan yang terbaik seperti disediakannya mesin ATMdisetiap kabupaten/ Kota yang ada kantor cabangnya.

\section{5) Promosi}

Merupakan sarana yang paling ampuh untuk menarik dan mempertahankan nasabah. Promosi merupakan bagian pemasaran Kebijakan promosi lembaga ini yang berkaitan dengan promosi meliputi penggunaan media cetak, audio, pamflet/brosur dan melakukan sosialisasi kepada warga. Selain itu mereka juga melakukan promosi melalui pengadaan pemeriksaan kesehatan gratis, beberapa promo ketika HUT CUSemarong.

Hasil wawancara mengenai promosi $\mathrm{CU}$ Semarong Tayan Hilir, melakukan promosi produk dengan membagikan brosur dijalanjalan dan biasanya mereka melakukan sosialisasi pada hari libur, karena kalau tidak hari libur masyarakat disina susah untuk berkumpul. Setiap perayaan ulang tahun CU Semarong melakukan beberapa kebijakan promosi, biasanya mereka memasang spanduk di depan kantornya, dan ada juga karyawan yang keliling mempromosikan. CU Semarong juga mempunyai produk untuk liburan wisata rohani, keluarga dan keluar daerah.

Dari hasil wawancara di atas mengenai kebijakan promosi yang diambil kopdit CU Semarong, cukup beragam, selain menggunakan brosur/ pamflet, CU semarong juga sering mengadakan aksi kemanusiaan, perlombaan, dan event-event lainnya.

\section{PEMBAHASAN}

a) Faktor- faktor yang mempengaruhi minat masyarakat dalam memilihproduk tabungan pada CU Semarong Tayan Hilir
Dari hasil wawancara dan observasi diperoleh gambaran bahwa minatmasyarakat dalam memilih produk tabungan pada $\mathrm{CU}$ Semarong Tayan Hilir, dipengaruhi oleh 2 faktor yang signifikan yaitu faktor lokasi, dan reputasi. Lokasi yang dekat dengan tempat tinggal beberapa nasabah, akses jalan yang baik, dekat dengan beberapa mini market. Selain itu nasabah juga tidak pernah mendengar CU semarong terlibat masalah hukum, dan mereka juga sering ikut dalam beberapa kegiatan sosial, misalnya mengadakan donor darah. Secara definisi promosi adalah merupakan kegiatan yang tujukan untuk mempengaruhi konsumen agar mereka dapat menjadi kenal akan produk yang ditawarkan oleh perusahaan kepada mereka dan kemudian mereka menjadi senang lalu membeli produk tersebut. Faktor Pribadi meliputi usia dan tahap siklus hidup, pekerjaan, keadaan ekonomi, kepribadian dan konsep diri, serta nilai dan gaya hidup pembeli, dapat menjadi sebuah ukuran dalam melihat peningkatan daya beli maasyarakat terhadap suatu produk. Promosi merupakan sarana yang paling ampuh untuk menarik dan mempertahankan nasabah.

Reputasi yang baik dan terpercaya merupakan sumber keunggulan bersaingsuatu bank. Pandangan paling dominan pada literatur menunjukkan bahwa sikap terhadap merek yaitu reputasi atau penyedia jasa lebih merupakan evaluasi keseluruhan jangka panjang dibanding elemen kepuasan.

Adanya reputasi yang baik dalam sebuah perusahaan bank akan menimbulkan kepercayaan bagi nasabahnya. Suatu kepercayaan adalah pikiran deskriptif oleh seorang mengenai suatu hal. Hal tersebut menjadi salah satu faktor utama masyarakat memilih menabung di CU Semarong Tayan Hilir. Minat pada hakekatnya minat merupakan sebab akibat dari pengalaman. Minat berkembang sebagai hasil daripada suatu kegiatan dan akan menjadi sebab akan dipakai lagi dalam kegiatan yang sama.

Berdasarkan temuan tersebut diatas dapat disimpulkan penentuan lokasi suatu usaha merupakan salah satu kebijakan yang sangat penting, karena dapat menjadi penentu keberhasilan suatu usaha. Salah satu faktor yang menarik minat masyarakat untuk menjadi anggota Credit Union (CU)Semarong 
adalah karena lokasi yang strategis sangat memudahkan nasabahdalam berurusan. Selain itu diperlukan reputasi yang baik untuk menumbuhkan rasa kepercayaan masyarakat, sehingga mampu bersaing dengan lembaga yang bergerak dibidang yang sama.

b) Minat masyarakat Kecamatan Tayan Hilir terhadap produk pinjaman yang di tawarkan oleh CU Semarong Tayan Hilir.

Minat masyarakat terhadap produk pinjaman dipengaruhi oleh faktor produk \& pengetahuan, kualitas pelayanan, dan promosi. Berdasarkan hasil wawancara, minat masyarakat untuk meminjam dipicu oleh kebutuhan.CU semarong menyediakanprodukproduk pinjaman yang sangat menarik, sesuai dengan kebutuhan nasabah. Pengetahuan tersebut mereka peroleh dari berbagai sumber seperti dari plang yang jelas terpasang di tepi jalan, kemudian dari brosur/ pamflet, ada juga dari kerabat mereka yang pernah meminjam disana. Dari temuan tersebut pengetahuan yang masyarakat peroleh dari berbagai sumber.

Pelayanan atau sistem administrasi ialah sebagai aktivitas yang diberikan untuk membantu, menyiapkan, dan mengurus baik itu berupa barang atau jasa dari satupihak ke pihak lain kualitas pelayanan pada Credit Union (CU)dapat berupa fasilitas fisik maupun pelayanan dari karyawannya. Fasilitas pelayanan yang nyaman serta memadai akan dapat menarik perhatian masyarakat dan membuat masyarakat nyaman dengan CU Semarong.

Hasil penelitian juga menemukan pelayanan yang mereka berikan juga baik, ramah, sopan, dan santun. CU semarong juga kerap mengadakan promosi pada perayaan hari-hari besar, misalnya HUT CU Semar ong, Natal, dan lain-lain. Selain faktor kualitas pelayanan ada juga faktor promosi yang berpengaruh signifikan terhadap pemilihan pinjaman yang ditawarkan CU Semarong, Promosi adalah semua kegiatan yang dimaksudkan untuk menyampaikan atau mengkomunikasikan suatu produk kepada pasar sasaran, untuk memberi informasi tentang keistimewaan, kegunaan dan yang paling penting adalah tentang keberadaannya, untuk mengubah sikap ataupun untuk mendorong orang untuk bertindak dalam membeli suatu produk.

Peneliti dalam penelitian ini akan menganalisis faktor minat masyarakat terhadap produk simpanan dan pinjaman Credit Union (CU) Semarong tayan hilir. Rendahnya minat masyarakat terhadap beberapa produk Credit Union (CU) Semarong, dan persaingan antar sesama lembaga keuangan menjadialasan dilakukan penelitian ini. Peneliti tertarik untuk mengetahui faktor apa saja yang mempengaruhi minat masyarakat dengan ditinjau dari Faktor Instrinsiknya yaitu pengetahuan, reputasi dan kualitas pelayanan. Serta faktor Ekstrinsik yaitu lokasi dan promosi dalam pengambilan keputusan untuk memilih produk simpanan dan pinjaman. Pilihan masyarakat terhadap produk Credit Union (CU) Semarong Kecamatan Tayan Hilir sangat ditentukan oleh apakah ia berminat atau tidak. Di dalam minat terkandung unsur motif atau dorongan dari dalam diri masyarakat yang merupakan daya tarik untuk melakuakn aktivitas atau kegiatan sesuai dengan tujuannya. Timbulnya minat masyarakat terhadap produk Credit Union (CU) Semarong Kecamatan Tayan Hilir juga dipengaruhi oleh adanya keinginan atau kebutuhan

\section{SIMPULAN DAN SARAN Simpulan}

Berdasarkan hasil penelitian kualitatif dengan teknik observasi, wawancara dan dokumentasi yang dilaksanakan di CU Semarong Tayan tentang analisis minat masyarakat terhadap produk CU Semarong Tayan dapat diambil kesimpulan. Kesimpulan tersebut dipaparkan sebagai berikut: minat masyarakat menabung dipengaruhi oleh 2 faktor yang signifikan yaitu faktor lokasi dan reputasi. Lokasi yang dekat, akses jalan yang baik, mempunyai nama baik sehingga nasabah merasa nyaman dan aman untuk memilih produk tabungan yang ada pada CU Semarong Tayan Hilir.Minat masyarakat memilih produk pinjaman di CU semarong tayan hilir dipengaruhi oleh 3 faktor dari Promosi, Pengetahuan Produk, dan Kualitas Pelayanan. Promosi yang dilakukan dengan membagikan pamflet/ brosur, melalui internet, dan media sosial, menyebarkan pengetahuan kepada 
masyarakat sehingga memunculkan rasa ingin tahu masyarakat untuk mengetahui lebih lanjut dengan mendatangi kantor cabang, pelayanan yangmereka berikan juga baik, sopan, santun, sehingga menarik minat masyarakat untuk meminjam di CU Semarong.

\section{SARAN}

Berdasarkan temuan pada faktor pengetahuan dan produk hasil penelitian dilapangan tentang jumlah anggota, peneliti menyarankan untuk $\mathrm{Cu}$ Semarong dapat mempromosikan secara optimal produkproduk yang masih kurang pemoinatnya misalnya pada produk SITOUR, SIHARTA dan SIPENDIK.

\section{DAFTAR RUJUKAN}

Abror, R. (2003). Penilaian Hasil Belajar. Bandung: PT Remaja Rosdakarya.

Astrid, S. (1999).Komunikasi dalam Teori dan Praktek.Jakarta: Bina Cipta.

Dannerius S. (1988). Sosiologi dan Antropologi. Klaten: PT. Intan Pariwara.

Djamrah, A. (2010). Media Pembelajaran. Yogyakarta : Gadjah Mada University Press.

Dr. Kasmir. (2015), Analisis Laporan Keuangan. Jakarta: Rajawali Per

Febianto, G. (2006). Pengaruh Lokasi, Tingkat Suku Bunga, Dan Reputasi Terhadap Keputusan Untuk Menabung (Studi Pada Badan Ke Swadayaan Masyarakat Sari Asih Kelurahan. Padang sari Kota Semarang). Semarang: Skripsi UNDIP Manajemen.

Handoyo, E. T. (2010). Model Pendidikan Karakter Berbasis Konservasi : Pengalaman Universitas Negri Semarang, Semarang, Universitas Negri Semarang dan Widya Karya.

Hardiansyah. (2011) Kualitas Pelayanan Publik: Konsep, Dimensi, Indikator dan Implementasinya. Yogyakarta : Gava Media.

Laksana, F. (2008). Manajemen Pemasaran Pendekatan Praktis edisi pertama :Graha Ilmu Yogyakarta.
Moleong, L. J. (2013. Metode Penelitian Kualitatif. Edisi Revisi. Bandung : PT.Remaja Rosdakarya.

Surya, M. (2004).PsikologiPembelajaran dan Pengajaran.Bandung:Pusta ka Bani Quraisy.

Munaldus,dkk. (2012). Credit Union: Kendaraan Menuju Kemakmuran, Praktek Bisnis Sosial Model Indonesia. Jakarta: PT. Alex Media Komputindo.

Sugiyono. (2013). Metode Penelitian Kualitatif, Kuantitatif, $R \& D$. Jakarta:Rineka Cipta.

Tjiptono, F. (2014). Pemasaran Jasa - Prinsip, Penerapan, dan Penelitian, Andi Offset, Yogyakarta. 